\title{
Assessment of NORM from oil refineries and fields northwest of Mosul
}

\author{
Mustafa A. Mahmoud ${ }^{1 *}$, Rasheed M. Yousuf ${ }^{2}$ \\ ${ }^{1 *, 2}$ Department of Environmental Sciences, College of Environmental Sciences and Technology, University of \\ Mosul, Mosul, IRAQ
}

E-mail: ${ }^{1 *}$ mustafaalsharook2019@gmail.com, 2 dr.rasheed@uomosul.edu.iq

(Received May 31, 2021; Accepted August 15, 2021; Available online December 01, 2021)

DOI: 10.33899/edusj.2021.130357.1164, (C) 2021, College of Education for Pure Science, University of Mosul.

This is an open access article under the CC BY 4.0 license (http://creativecommons.org/licenses/by/4.0/).

\begin{abstract}
The uranium concentration and radioactivity of radon gas were measured in Al-Kasik refinery and Ain Zala field using the CR-39 detector. Soil and water samples associated with the production stages of oil, sludge and crude oil were collected. The levels of uranium concentration in soil ranged from 0.703 to $1.480 \mathrm{ppm}$, in water samples from 0.681 to $0.716 \mathrm{ppm}$, in sludge samples from 0.849 to $1.014 \mathrm{ppm}$, and in crude oil from 0.785 to $0.933 \mathrm{ppm}$. As for the radioactivity of radon gas, when comparing the radon rate in the samples we obtained with the global values, it was found that it falls within the internationally permissible limit, where the radon rate in the soil was $12.81 \mathrm{~Bq} / \mathrm{kg}$ and when compared with the United Nations Scientific Committee on the Effects of Atomic Radiation (UNSCEAR) which has a value of 32 $\mathrm{Bq} / \mathrm{kg}$, and in the produced water it was $8.66 \mathrm{~Bq} / \mathrm{kg}$ compared to (UNSCEAR)which has a value of 50 $\mathrm{Bq} / \mathrm{kg}$. In sludge samples $11.81 \mathrm{~Bq} / \mathrm{kg}$ and when compared with the International Atomic Energy Agency (IAEA) whose value is $\left(8-5 \times 10^{5}\right) \mathrm{Bq} / \mathrm{kg}$, and in crude oil samples $10.56 \mathrm{~Bq} / \mathrm{kg}$ and when compared with the International Federation of Oil and Gas Producer (IOGP) whose value is (800 $4 \times 10^{5}$ ) Bq $/ \mathrm{kg}$. As for the alpha ray hazard index, the results showed that it is within the permissible limits internationally, where the results were less than 1 and therefore does not pose a threat to the health of workers and environment.
\end{abstract}

Keywords: NORM ;Oil and Gas; Radioactivity; Produced water; Sludge

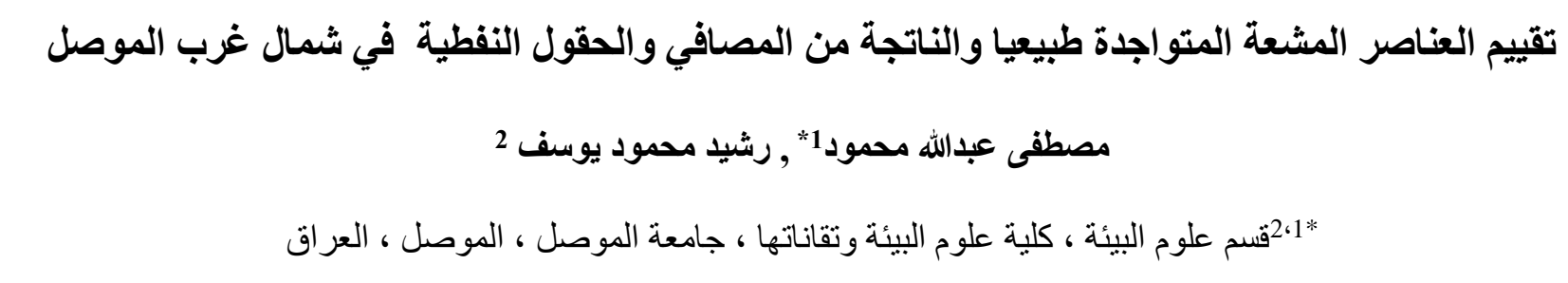

الخلاصة

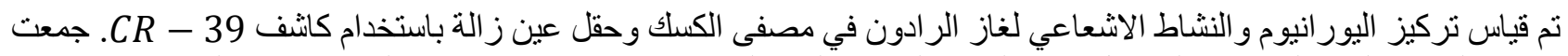

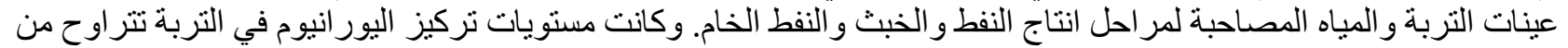

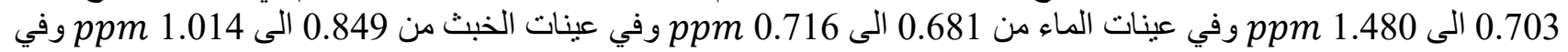
النفط الخام من 0.785 الى 0.933 الم 0.480. النشاط الاشعاعي لغاز الر ادون عند مقارنة معدل الر ادون في العينات التي حصلنا عليها 


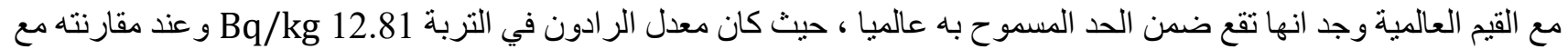

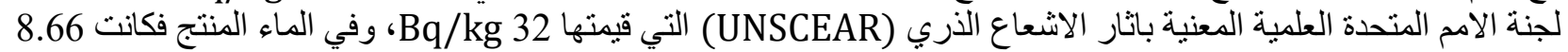

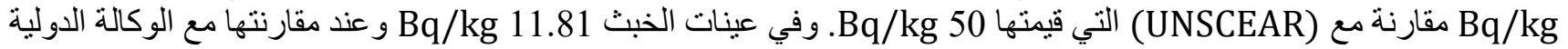

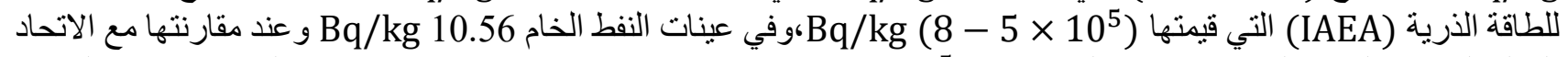

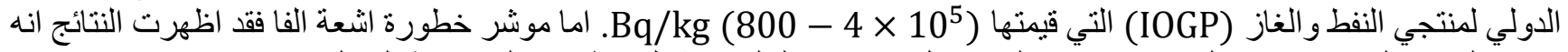

$$
\begin{aligned}
& \text { ضمن الحدود المسموح بها عالميا حيث كانت النتائج اقل من } 1 \text { وبالتالي لاتثكل خطورة على صحة العاملين. } \\
& \text { الكلمات المفتاحية: نورم ، النفط و الغاز ، النشاط الإنشعاعي ، المياه المصاحبة لانتاج النفط ، الخبث }
\end{aligned}
$$

\section{Introduction}

Human beings are exposed to natural radiation that comes from two main source is cosmic rays that come from outer space and are produced by the glow of the sun and from external galaxies, as well as the natural terrestrial radiation, and the second source is the natural radioactive elements where these elements are widely spread in the earth's crust [1].

The term (NORM) used in the oil and gas industry stands for natural radioactive materials such as uranium and thorium. The radionuclides that are measured in the oil and gas industry are the result of the dissolution of two natural chains, uranium U238 and thorium Th232, where these elements have a long half-life and their presence in the soil depends on the geological structure [2].Natural radionuclides are present in oil and gas reservoirs in varying concentrations. These nuclides are released when oil and gas is extracted from the ground, to accompany oil and water to the surface of the earth, and move to production equipment such as pipelines and oil tanks, and settle inside them within the slag and crusts materials [3]. Workers in the oil and gas industry are exposed to radioactive materials during oil extraction, as well as exposure to mud, and water while drilling oil wells, in addition to that during equipment maintenance and tank cleaning. There are several studies and reports, related to NORM in the oil industry, where the International Atomic Energy Agency (IAEA) [4] has,published safety and security reports on dealing with NORM . Additionally, the International Association of Oil and Gas Producers (OGP) [5] has, published clarifications about NORM in the oil and gas industry, and the United Nations Scientific Committee concerned with the effects of atomic radiation (UNSCEAR) [6] has published several reports on NORM and provided detailed sexplanation. In Egypt, researchers were able to study the level of NORM in the slag resulting from the oil industry and determine the level of its danger [7]. In Turkey, radium isotopes have been studied in waste and crude oil produced from the oil industry [8]. Our current study aims to measure the concentration of uranium and the radioactivity of radon gas, determine the danger of alpha that affects workers in the oil and gas industry, and compare the obtained results with the internationally permissible limit, including the United Nations Scientific Committee on the Effects of Atomic Radiation (UNSCEAR), the International Atomic Energy Agency (IAEA), and the International Association of Oil and Gas Producers (OGP).

\section{Study Area}

The area of this study, as shown in Figure -1 includes the Alksak refinery, located $60 \mathrm{~km}$ northwest of Mosul, and shown Figure -2 the Ain Zala field, which is $120 \mathrm{~km}$ northwest of Mosul 


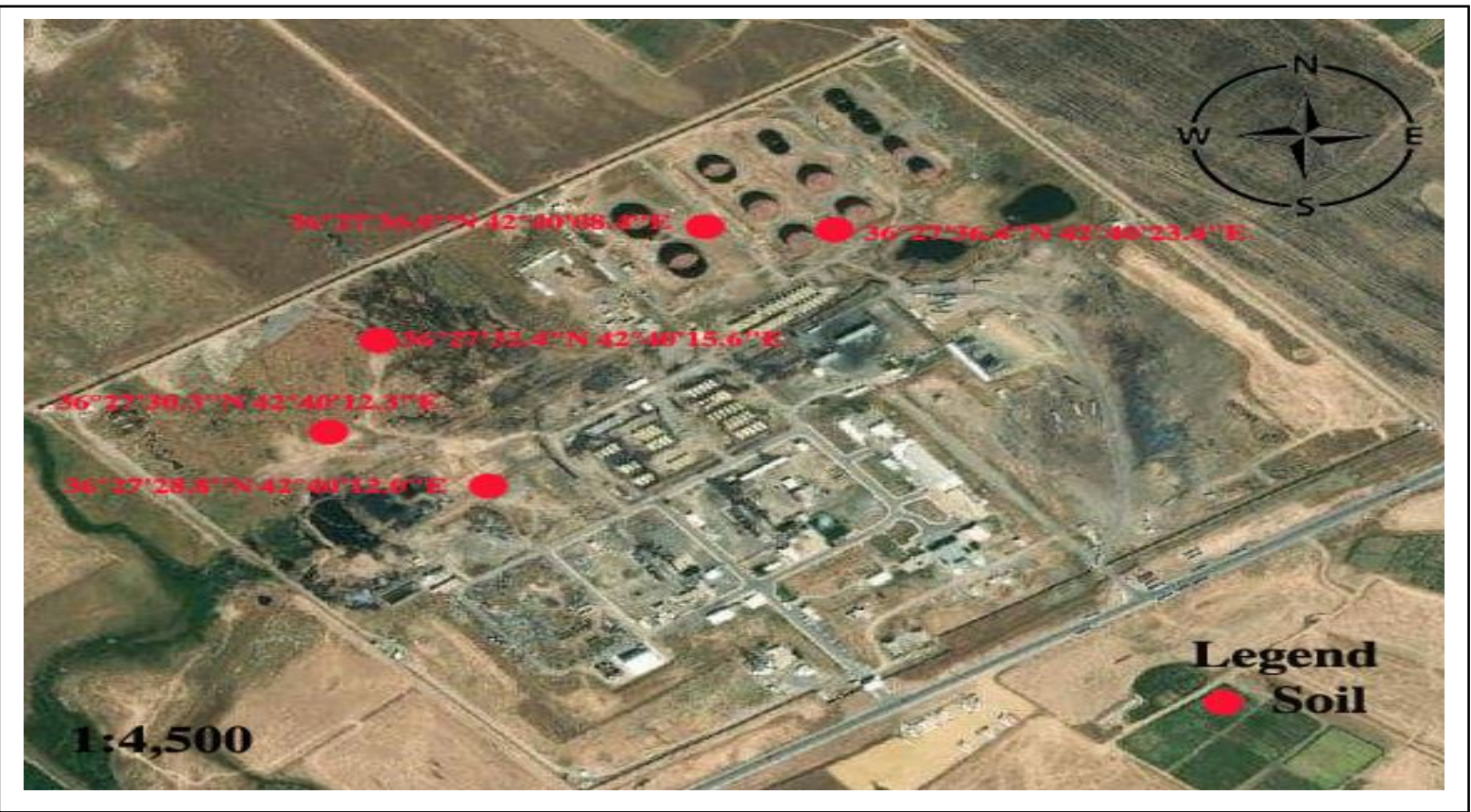

Figure - 1 A map shows the location of Alksak refinery

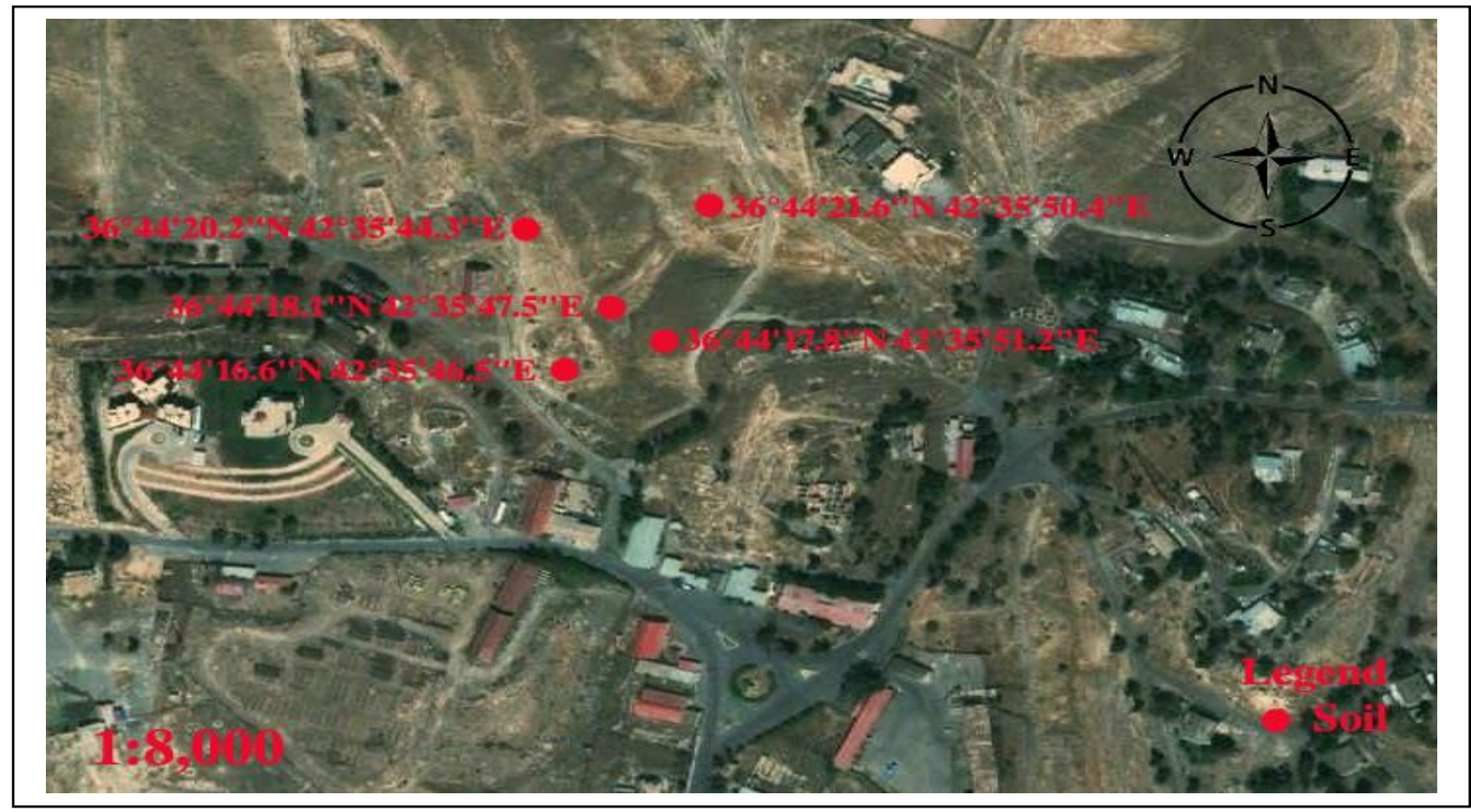

Figure - 2 A map shows the location of Ain Zala field

\section{Samples Collection}

two-Twenty different samples were collected from Ain Zala field and Al-Kasak refinery. The samples included soil, production water, sludge, and crude oil samples. Fifteen soil samples were collected from 
two previously mentioned sites, whereas soil samples were collected from around the oil tanks and some of the site. In the Ain Zala field, samples were taken from around the oil wells. Soil samples were taken at a depth of $0-15 \mathrm{~cm}$ and stored in airtight plastic bags. As for slag, two samples were taken from the previously mentioned study sites, and sludge samples were taken from oil tanks and stored in plastic bags as well. Two samples of production water were also taken from a wet gas treatment unit and then placed into one liter (1 liter) plastic containers, and crude oil samples were taken from one of the tanks and stored in (1 liter) plastic containers with a label. The type of sample, the location, and the date the sample was taken is written on each sample .

\section{Sample Preparation}

Soil and sludge samples were exposed to a heat source for several hours in order to remove moisture from them. Impurities and gravel were removed from samples using a sieve of $2 \mathrm{~mm}$ diameter. Samples were grinded and a fine powder was obtained. Samples were weighed using a sensitive balance , as for the production water and Crude Oil samples, they remained as they are. After that, all samples were placed inside plastic cups which were sealed to prevent the occurrence of interaction between the air inside the samples and their external surroundings, where the samples were left for 30 days to achieve the ideal balance between radium and radon, reaching $98 \%$ of the ideal equilibrium state. This time is calculated through the equilibrium relationship of radioactivity [9] [10]:

$A_{\mathrm{Rn}}=A_{R a}\left(1-e^{-\lambda R n t}\right)$

Where $A_{\mathrm{Rn}}$ effective means radon and $A_{R a}$ and represents the effectiveness of radium and $\lambda_{R n}$ represents the radon decay constant $0.1814 \mathrm{~d}^{-1}$ and $t$ is the time required to reach equilibrium.

\section{Measurements}

The concentration of uranium and specific radioactivity of radon gas was measured for all samples using the solid state nuclear trace detector CR-39, where the samples were placed in irradiation chambers consisting of two plastic cups with identical size and shape, placing a filter paper between them and closing the mugs with adhesive tape tightly. The CR-39 detectors were left inside the chambers for 30 days [11] [12]. After that, the chemical $6.25 \mathrm{~N} \mathrm{NaOH}$ erosive solution was prepared. At the end of the experiment, the reagents were removed and placed inside the chemical erosive solution and placed inside the water bath at a temperature of $70{ }^{\circ} \mathrm{C}$ for 3 hours. The radiation background reached $180 \mathrm{Tr} . \mathrm{cm}^{-2}$ and was subtracted from the intensity of the effects of alpha particles emitted from the samples under study. Microscopic observation was carried out using an optical microscope with a magnification of 400X. Figure 3 shows the irradiation system that was used.

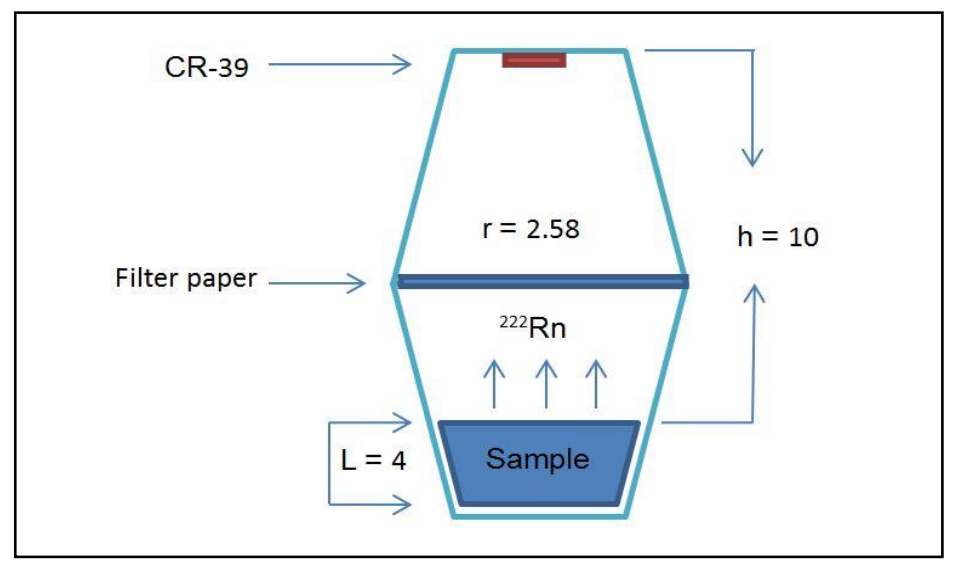

Figure 3 Irradiation system 
The following equations numbered (1) to (7) were used for calculation :

1- Measure the concentration of radon gas through the following relationship [13]

$\mathrm{P}=\mathrm{KC}_{\mathrm{a}} \mathrm{T} \ldots \ldots \ldots \ldots \ldots 1$

Where $\mathrm{P}\left(\mathrm{Tr} . \mathrm{cm}^{-2}\right)$ represents tracks density, $\mathrm{K}\left(\mathrm{Tr} \cdot \frac{\mathrm{cm}^{-2}}{\mathrm{~h}^{-1} \mathrm{~Bq} \cdot \mathrm{m}^{-3}}\right)$ represents the diffusion constant, $\mathrm{T}$ represents the irradiation time in hours, and $\mathrm{C}_{\mathrm{a}}$ represents the radioactivity of radon in the air space in units (Bq. $\mathrm{m}^{-3}$ ).

2- Determination of the propagation constant $\mathrm{k}$ [14]:

$\mathrm{K}=\frac{1}{4} \mathrm{r}\left(2 \operatorname{Cos} \theta-\frac{\mathrm{r}}{\mathrm{R} \alpha}\right) \ldots \ldots \ldots \ldots .2$

Where $r$ represents the radius of the cup and is equal to $2.58 \mathrm{~cm}$ and $\mathrm{R} \alpha$ represents the range of alpha particles in the air produced by radon and is equal to $4.16 \mathrm{~cm}$ and represents the $\theta$ angle of $35^{\circ}$

3- Determining of radon concentration in samples $\left(\mathrm{C}_{\mathrm{s}}\right)$ :

The radon concentration in the samples was calculated by the following relationship:

$\mathrm{C}_{\mathrm{S}}=\mathrm{h} \lambda_{\mathrm{Rn}} \mathrm{T} \frac{\mathrm{C}_{\mathrm{a}}}{\mathrm{L}} \ldots \ldots \ldots \ldots \ldots 3$

Where $C_{s}$ represents the radon activity within the samples in units (Bq. $\mathrm{m}^{-3}$ ), $\mathrm{h}$ represents the height of detector from the sample surface in $\mathrm{cm}$ units, $\mathrm{T}$ represents the irradiation time in days,$\lambda_{\mathrm{Rn}}$ represents the radon decay constant and L represents the thickness of the sample in $\mathrm{cm}$.

4- The radioactivity of radon gas produced from samples $(\mathrm{Bq})$ unit :

$\mathrm{A}_{\mathrm{Rn}}=\mathrm{C}_{\mathrm{S}} \mathrm{V} \quad \ldots \ldots \ldots \ldots \ldots . \ldots$

$\mathrm{V}={\mathrm{L} \pi \mathrm{r}^{2}}^{2} \quad \ldots \ldots \ldots \ldots \ldots . . . . . .5$

Where $A_{R n}$ the radioactivity of radon gas in the samples $(B q)$ unit And V volume samples $\left(\mathrm{m}^{3}\right)$ and $r^{2}$ radius equal $2.58(\mathrm{~cm})$.

5- Finding the number of radon atoms $\mathrm{N}_{\mathrm{Rn}}$ in the samples :

$A_{\mathrm{Rn}}=\mathrm{N}_{\mathrm{Rn}} \lambda_{\mathrm{Rn}} \ldots \ldots \ldots .6$

After determining the number of radon atoms, the number of uranium atoms is found through the law of radiation balance

$\lambda_{\mathrm{U}} \mathrm{N}_{\mathrm{U}}=\lambda_{\mathrm{Rn}} \mathrm{N}_{\mathrm{Rn}} \ldots \ldots \ldots .7$

6- Determining the mass of uranium in the samples :

$\mathrm{W}_{\mathrm{U}}=\mathrm{N}_{\mathrm{U}} \mathrm{A}_{\mathrm{U}} / \mathrm{N}_{\mathrm{av}} \ldots \ldots \ldots \ldots \ldots . . . . . .8$

Where $W_{U}$ represents the mass of uranium in the samples, $A_{U}$ represents the mass number of uranium, and $\mathrm{N}_{\mathrm{av}}$ represents the number of Avogadro, $\mathrm{N}_{\mathrm{U}}$ number of uranium atoms in the samples .

7- Determining the uranium concentration(CU) in samples in ppm units :

$\operatorname{ppm}=\frac{\mathrm{W}_{\mathrm{U}}}{\mathrm{W}_{\mathrm{S}}} \quad \ldots \ldots \ldots \ldots . . . . .9$

Where $W_{S}$ represents the mass of the sample in $(\mathrm{gm})$. 


\section{Results and Discussion}

Table 1 shows the location of the sample, its type, the sample weight, number of traces, and the radon concentration in the air and the samples. The results show that the highest radioactivity of radon gas and the concentration of uranium in soil, where the radon value soil samples in Alksak refinery were 18.06 $\mathrm{Bq} / \mathrm{kg}$, the uranium concentration was $0.941 \mathrm{ppm}$, while the lowest values of radioactivity were for radon gas and the concentration of uranium in Alksak refinery; the radon value was of $8.7 \mathrm{~Bq} / \mathrm{kg}$ and the value of uranium concentration was $0.703 \mathrm{ppm}$. when comparing the results that were obtained with the permissible limits UNSEARS (32) Bq/kg [6] .As the results were within the permissible global limit, therefore they pose no risk to humans. In sludge samples, the highest radioactivity of radon gas $(12.62 \mathrm{~Bq} / \mathrm{kg}$ ) and the concentration of uranium was in Ain Zala field $1.019 \mathrm{ppm}$, and the lowest radioactivity of radon gas and the concentration of uranium were in sample entry number 19 in table 1 for Ain Zala field with a value of $10.52 \mathrm{~Bq} / \mathrm{kg}$ and uranium with a concentration of $0.849 \mathrm{ppm}$. The sludge results obtained with IAEA $\left(8-5 \times 10^{5} \mathrm{~Bq} / \mathrm{kg}[1]\right.$ show that the results are within the universally permitted limit. As for the crude oil sample, the highest radioactivity of radon gas and the concentration of uranium in Ain Zala field where the radon value was $11.56 \mathrm{~Bq} / \mathrm{kg}$, uranium with a concentration of $0.785 \mathrm{ppm}$. The lowest radioactivity value of radon gas and the lowest concentration of uranium was in AlKasik refinery and the lowest concentration of uranium was in AlKasik refinery 9.73 $\mathrm{Bq} / \mathrm{kg}$ for radon and $0.933 \mathrm{ppm}$ for uranium concentration, compared to the permissible limit. For the OGP $\left(800-4 \times 10^{5}\right) \mathrm{Bq} / \mathrm{kg}[15]$, we find that it is within the universally permitted limit. As for the water samples associated with the production of sludge, the highest radioactivity value was for radon gas in Ain Zala field $8.88 \mathrm{~Bq} / \mathrm{kg}$, and the highest uranium concentration was in Ain Zala and uranium with a concentration of $0.716 \mathrm{ppm}$. The lowest radioactivity of radon and the uranium concentration was in Alksak refinery $8.44 \mathrm{~Bq} / \mathrm{kg}$ and uranium at a concentration of $0.681 \mathrm{ppm}$ When comparing the results we obtained with the permissible limit UNSEAR ( 50) Bq/kg [16] we find that what we obtained is within the permissible limits globally. As for the level of risk of alpha rays, all results were within the global permissible limit $1 \leq$ and thus do not form a risk to the health of workers in the oil industry. Figure 4 shows the rate of radioactivity of radon in the samples, where it was found that the rate of radioactivity of radon in soil is $12.81 \mathrm{~Bq} / \mathrm{kg}$, water produced $8.66 \mathrm{~Bq} / \mathrm{kg}$ and sludge $11.81 \mathrm{~Bq} / \mathrm{kg}$, and Crude Oil $10.65 \mathrm{~Bq} / \mathrm{kg}$

Table 1- the location of the sample, its type, the sample weight, number of traces, and the radon concentration in the air and the samples

\begin{tabular}{|c|c|c|c|c|c|c|c|}
\hline NO & Location & Material & $\boldsymbol{A}_{\boldsymbol{R n}}(\boldsymbol{B q})$ & $\boldsymbol{A}_{\boldsymbol{R n}}(\boldsymbol{B q} / \mathbf{k g}$ & $\begin{array}{l}\boldsymbol{N}_{\boldsymbol{U}} \\
\times \mathbf{1 0}^{\mathbf{1 7}}\end{array}$ & $\boldsymbol{W}_{\boldsymbol{U}} \times \mathbf{1 0}^{-\mathbf{6}}$ & $\boldsymbol{C} \boldsymbol{U}(\boldsymbol{p p m})$ \\
\hline 1 & Alksak refinery & Soil & 0.9372 & 11.67 & 1.913 & 75.630 & 0.941 \\
\hline 2 & Alksak refinery & Soil & 1.4508 & 18.06 & 2.961 & 117.063 & 1.457 \\
\hline 3 & Alksak refinery & Soil & 0.9941 & 12.55 & 2.435 & 96.267 & 1.215 \\
\hline 4 & Alksak refinery & Soil & 1.2045 & 14.99 & 2.458 & 97.177 & 1.209 \\
\hline
\end{tabular}


Table 2- the radioactivity of radon $(B q)$, the radioactivity of radon $(B q / \mathrm{kg})$, the number of uranium atoms, the mass of uranium in the samples, the concentration of uranium( $p p m$ ) in the samples, and the alpha index.

\begin{tabular}{|c|c|c|c|c|c|c|c|}
\hline NO & Location & Material & $\begin{array}{c}\text { Track } \\
\text { Tr. } \text { cm }^{-2}\end{array}$ & $\begin{array}{c}C_{s} \\
\text { Bq. } m^{-3} 10^{3}\end{array}$ & $\begin{array}{c}C_{a} \\
B q \cdot m^{-3} 10^{3}\end{array}$ & $\begin{array}{c}\text { Sample } \\
\text { weight } \\
\text { (gm) }\end{array}$ & $\begin{array}{c}\text { The } \\
\text { coordinates } \\
\text { of the site }\end{array}$ \\
\hline 1 & Alksak refinery & Soil & 1402 & 0.824 & 11.2105 & 80.33 & $\begin{array}{l}36^{\circ} 27^{\prime} 43.2^{\prime \prime} \mathrm{N} \\
42^{\circ} 40^{\prime} 26.4^{\prime \prime} \mathrm{E}\end{array}$ \\
\hline 2 & Alksak refinery & Soil & 1809 & 1.063 & 17.3545 & 80.33 & $\begin{array}{l}36^{\circ} 27^{\prime} 39.6^{\prime \prime} \mathrm{N} \\
42^{\circ} 40^{\prime} 19.2^{\prime \prime} \mathrm{E}\end{array}$ \\
\hline 3 & Alksak refinery & Soil & 1487 & 0.874 & 11.8908 & 79.23 & $\begin{array}{l}36^{\circ} 27^{\prime} 28.8^{\prime \prime} \mathrm{N} \\
42^{\circ} 40^{\prime} 12.0^{\prime \prime} \mathrm{E}\end{array}$ \\
\hline 4 & Alksak refinery & Soil & 1801 & 1.059 & 14.4077 & 80.33 & $\begin{array}{l}36^{\circ} 27^{\prime} 30.3^{\prime \prime} \mathrm{N} \\
42^{\circ} 40^{\prime} 12.3^{\prime \prime} \mathrm{E}\end{array}$ \\
\hline 5 & Alksak refinery & Soil & 1046 & 0.615 & 8.3671 & 80.33 & $\begin{array}{l}36^{\circ} 27^{\prime} 32.4^{\prime \prime} \mathrm{N} \\
42^{\circ} 40^{\prime} 15.6^{\prime \prime} \mathrm{E}\end{array}$ \\
\hline 6 & Alksak refinery & Sludge & 1522 & 0.895 & 12.1765 & 81.00 & $\begin{array}{l}36^{\circ} 27^{\prime} 35.0^{\prime \prime} \mathrm{N} \\
42^{\circ} 40^{\prime} 20.7^{\prime \prime} \mathrm{E}\end{array}$ \\
\hline 7 & Alksak refinery & $\begin{array}{l}\text { water } \\
\text { produced }\end{array}$ & 987 & 0.579 & 7.877 & 78 & $\begin{array}{l}36^{\circ} 27^{\prime} 32.4^{\prime \prime} \mathrm{N} \\
42^{\circ} 40^{\prime} 15.6^{\prime \prime} \mathrm{E}\end{array}$ \\
\hline 8 & Ain Zala field1 & Soil & 1759 & 1.034 & 14.0676 & 79.23 & $\begin{array}{l}36^{\circ} 44^{\prime} 20.2^{\prime \prime} \mathrm{N} \\
42^{\circ} 35^{\prime} 44.3^{\prime \prime} \mathrm{E}\end{array}$ \\
\hline 9 & Ain Zala field1 & Soil & 1517 & 0.892 & 12.1357 & 79.23 & $\begin{array}{l}36^{\circ} 44^{\prime} 18.1^{\prime \prime} \mathrm{N} \\
42^{\circ} 35^{\prime} 47.5^{\prime \prime} \mathrm{E}\end{array}$ \\
\hline 10 & Ain Zala field1 & Soil & 1784 & 1.049 & 14.2716 & 79.23 & $\begin{array}{l}36^{\circ} 44^{\prime} 16.6^{\prime \prime} \mathrm{N} \\
42^{\circ} 35^{\prime} 46.5^{\prime \prime} \mathrm{E}\end{array}$ \\
\hline 11 & Ain Zala field 1 & Soil & 2175 & 1.278 & 17.3872 & 79.23 & $\begin{array}{l}36^{\circ} 44^{\prime} 17.8^{\prime \prime} \mathrm{N} \\
42^{\circ} 35^{\prime} 51.2^{\prime \prime} \mathrm{E}\end{array}$ \\
\hline 12 & Ain Zala field1 & Soil & 1805 & 1.061 & 14.4349 & 79.23 & $\begin{array}{l}36^{\circ} 44^{\prime} 21.6^{\prime \prime} \mathrm{N} \\
42^{\circ} 35^{\prime} 50.4^{\prime \prime} \mathrm{E}\end{array}$ \\
\hline 13 & Ain Zala field2 & Soil & 1340 & 0.788 & 10.7207 & 78.23 & $\begin{array}{l}36^{\circ} 43^{\prime} 28.8^{\prime \prime} \mathrm{N} \\
42^{\circ} 35^{\prime} 32.3^{\prime \prime} \mathrm{E}\end{array}$ \\
\hline 14 & Ain Zala field2 & Soil & 1670 & 0.982 & 13.3601 & 79.23 & $\begin{array}{l}36^{\circ} 43^{\prime} 28.5^{\prime \prime} \mathrm{N} \\
42^{\circ} 35^{\prime} 31.5^{\prime \prime} \mathrm{E}\end{array}$ \\
\hline 15 & Ain Zala field2 & Soil & 1786 & 1.049 & 14.2716 & 78.23 & $\begin{array}{l}36^{\circ} 43^{\prime} 29.6^{\prime \prime} \mathrm{N} \\
42^{\circ} 35^{\prime} 30.2^{\prime \prime} \mathrm{E}\end{array}$ \\
\hline 16 & Ain Zala field2 & Soil & 1410 & 0.829 & 11.2785 & 78.23 & $\begin{array}{l}36^{\circ} 43^{\prime} 30.1^{\prime \prime} \mathrm{N} \\
42^{\circ} 35^{\prime} 32.3^{\prime \prime} \mathrm{E}\end{array}$ \\
\hline 17 & Ain Zala field2 & Soil & 1145 & 0.673 & 9.1562 & 78.23 & $\begin{array}{l}36^{\circ} 43^{\prime} 28.4^{\prime \prime} \mathrm{N} \\
42^{\circ} 35^{\prime} 31.2^{\prime \prime} \mathrm{E}\end{array}$ \\
\hline 18 & Ain Zala field1 & Sludge & 1461 & 0.859 & 11.6867 & 77.40 & $\begin{array}{l}36^{\circ} 43^{\prime} 14.1^{\prime \prime} \mathrm{N} \\
42^{\circ} 35^{\prime} 34.9^{\prime \prime} \mathrm{E}\end{array}$ \\
\hline 19 & Ain Zala field2 & Sludge & 1276 & 0.749 & 10.1901 & 81.00 & $\begin{array}{l}36^{\circ} 43^{\prime} 15.0^{\prime \prime} \mathrm{N} \\
42^{\circ} 35^{\prime} 39.6^{\prime \prime} \mathrm{E}\end{array}$ \\
\hline 20 & Ain Zala field & $\begin{array}{c}\text { water } \\
\text { produced }\end{array}$ & 1038 & $\begin{array}{l}0.609 \\
\mathbf{5 0}\end{array}$ & 8.285 & 78 & $\begin{array}{l}36^{\circ} 43^{\prime} 22.3^{\prime \prime} \mathrm{N} \\
42^{\circ} 35^{\prime} 37.6^{\prime \prime} \mathrm{E}\end{array}$ \\
\hline 21 & Ain Zala field & oil & 1350 & 0.667 & 10.7888 & 78 & $\begin{array}{l}36^{\circ} 43^{\prime} 12.5^{\prime \prime} \mathrm{N} \\
42^{\circ} 35^{\prime} 37.6^{\prime \prime} \mathrm{E}\end{array}$ \\
\hline 22 & Alksak refinery & oil & 1135 & 0.793 & 9.0745 & 78 & $\begin{array}{l}36^{\circ} 27^{\prime} 35.0^{\prime \prime} \mathrm{N} \\
42^{\circ} 40^{\prime} 20.7^{\prime \prime} \mathrm{E}\end{array}$ \\
\hline
\end{tabular}




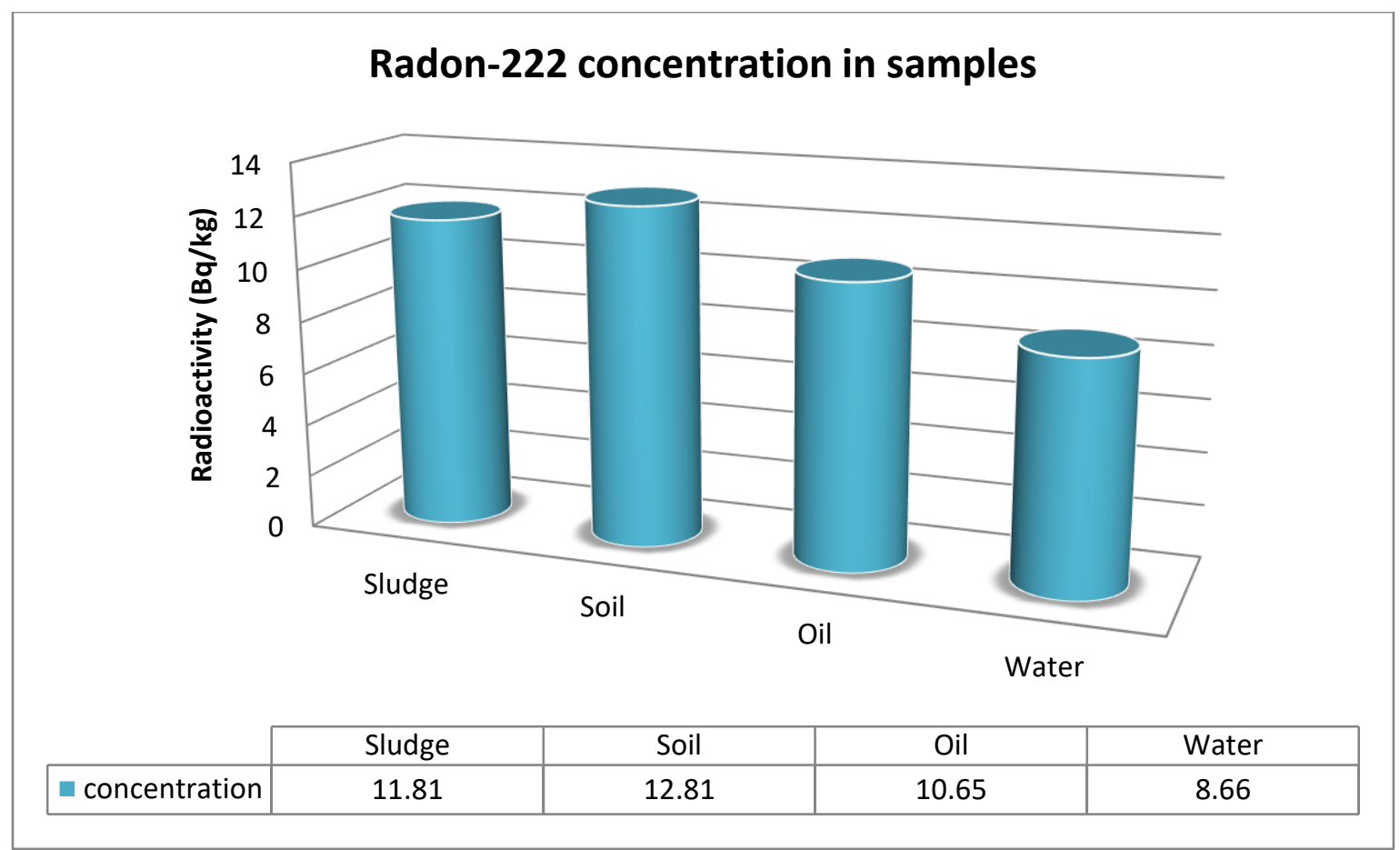

Figure 3 shows the rate of radioactivity of radon in the samples, where it was found that the rate of radioactivity of radon in soil is $12.81 \mathrm{~Bq} / \mathrm{kg}$, water produced $8.66 \mathrm{~Bq} / \mathrm{kg}$ and sludge $11.81 \mathrm{~Bq} / \mathrm{kg}$, and Crude Oil . 10.65 Bq/kgThe radon rate obtained in the collected samples is within the permissible limits when compared with global values .

Table 3- Comparison of NORM concentration with unit $\mathrm{Bq} / \mathrm{kg}$ of the current study with other studies

\begin{tabular}{|c|c|c|c|}
\hline NO & Sample & $R n_{222}-\left(R a_{226}\right)$ & Refrence \\
\hline 1 & Worldwide average(soil) & 32 & [6] \\
\hline 2 & Oman NORM(Sludge) & 547 & [17] \\
\hline 3 & China (Surface soil) & 12.6 & [18] \\
\hline 4 & OGP (Crude oil) & $800-4 \times 10^{5}$ & {$[15]$} \\
\hline 5 & IAEA (Sludge) & $8-5 \times 10^{5}$ & [1] \\
\hline 6 & Iraq (sludge) & $68.7-312.8$ & \multirow[t]{4}{*}{ [19] } \\
\hline 7 & Iraq (Soil) & $49.8-97.6$ & \\
\hline 8 & Iraq (Produced water) & $20.3-67.3$ & \\
\hline 9 & Oil ( Iraq) & $18.6-33.6$ & \\
\hline 10 & Iraq NORM (Sludge) & $1.8-252$ & \multirow[t]{5}{*}{ [20] } \\
\hline 11 & Iraq NORM (Crude Oil) & $2.3-5.8$ & \\
\hline 12 & Iraq (sludge) & $6.8-14.4$ & \\
\hline 13 & Iraq (Surface soil) & $3.7-43.3$ & \\
\hline 14 & Iraq (Formation water) & 8.8 & \\
\hline 15 & Iraq (Soil) & $8.71-18.35$ & \multirow[t]{4}{*}{ This work } \\
\hline 16 & Iraq NORM (Sludge) & $10.52-12.62$ & \\
\hline 17 & Iraq NORM (Crude Oil) & $9.73-11.56$ & \\
\hline 18 & Iraq (Produced water) & $8.44-8.88$ & \\
\hline 19 & Worldwide average( Produced water) & 50 & [16] \\
\hline
\end{tabular}




\section{Conclusions}

The radioactivity of radon gas and the concentration of uranium were calculated in the samples collected from Al-Kasak refinery and Ain Zala field. The results showed that the average concentration of uranium for soil samples, produced water, slag and crude oil was within the internationally permissible limit. The level of danger of alpha rays was calculated. The results we obtained were less than 1 and therefore do not constitute any danger to the health of workers and the environment.

\section{Acknowledgments}

I extend my sincere thanks and appreciation to everyone who helped me or guided me to complete this research , the North Oil Company, represented by its director, the late Eng. Bashir Muhammad Murad, Engineer Mahmoud Al-Jarjri, and the North Refineries Company represented by Engineer Muhammad Khadar, Engineer Shit and Engineer Younas.

\section{References}

[1] IAEA. Radiation Protection and the Management of Radioactive Waste. Vienna: IAEA Technical Report Series No. 34. (2003).

[2]H.M.Abdelbary,E.A.Elsofany,Y.T.Mohamed,M.M.AboAly,M.F.Attallah"Characterization and radiological impacts assessment of scale TENORM waste produced from oil and natural gas production in Egypt". Environmental Science and Pollution Research, 26(30), 30836-30846.(2019).

[3] E.O.Olalekan,F.M.Adebiyi."Measurement of radioactivity levels in oil impacted soils around petroleum products retailing stations". Petroleum Science and Technology, 38(1), 53-63.(2020).

[4] IAEA. Management of NORM Residues. Vienna: International atomic energy agency. (2013).

[5] OGP. Managing Naturally Occurring Radioactive Material (NORM) in the oil and gas industry. Report No. 412. (2016).

[6] UNSCEAR. Health effects due to radiation from the Chernobyl accident Draft. report A/AC," 82/R.673, 1220.220, United Nations Scientific Committee on the Effects of Atomic Radiation. (2008).

[7] M.F.Attallah,H.M.Abdelbary,E.A.Elsofany,Y.T. Mohamed,M.M.Abo-Aly,"Radiation safety and environmental impact assessment of sludge TENORM waste produced from petroleum industry in Egypt". Process Safety and Environmental Protection, 142, 308-316.(2020).

[8]A.Parmaksı,,Y.Agus,F.Bulgurlu,E.Bulur,T.oncuY.O.ozkok,"Measurement of enhanced radium isotopes in oil production wastes in Turkey". Journal of environmental radioactivity, 141, 82-89.(2015).

[9] S.H.Saeed,S.Y.Hassan,"Determination of Radon, Uranium and Other Radioactive Isotopes' Concentration in Different Types of Natural Water in Nenava Governorate". JORDAN JOURNAL OF PHYSICS, 8(4), 227 244.(2015).

[10] L.A.Najam, M.S.Karim, H.A., T. K., Hameed," Measurement of radon gas concentration in tap water samples in Wassit governorate by using nuclear track detector (CR-39)". International Journal of Physics, 4(5), 119-122.(2016). 
[11] A.M.Mohammad," Measurement of radon-222 concentration in soil samples of some sulfuric spring in hit city using CR-39 detector". Baghdad Science Journal, 8(4), (2011).

[12] A.A.Ridha, M.S.Karim, N.F.Kadhim," Measurement of radon gas concentration in soil and water samples in Salahaddin Governorate-Iraq using nuclear track detector (CR-39)". Civil and Environmental Research, 6(1), 24-30.(2014).

[13] H Ali, A., K Mh, A., \& I Hassan, H,"Determination of the Background Radiation Level in Mosul University Campus Using Multiple Technologies". Rafidain Journal of Science, 25(5), 86-100.(2014).

[14] M Al-Badrani, MDetermination of Radioactive Contamination of Plant Fertilizers Using CR-39. Rafidain Journal of Science, 17(6), 1-10.2006)).

[15] OGP. Guidelines for the management of Naturally Occuring Radioactive Material (NORM) in the oil and gas industry," International Association of Oil \& Gas Producers. Report No.412. (2008).

[16] UNSCEAR United Nations Committee on the Effect of Atomic Radiation. Sources and NCRP. Exposure of the population in the United States and Canada from natural background radiation. NCRP report no.94, National Council on Radiation Protection and Measurement. (1994).

[17] A.N.Al-Farsi, "Radiological aspects of petroleum exploration and production in the Sultanate of Oman" (Doctoral dissertation, Queensland University of Technology). (2008)

[18] Hu, B., Wang, C., Xu, X., Zhang, S., Bao, S., \& Li, Y. Assessment of radioactive materials and heavy metals in the surface soil around uranium mining area of Tongliao, China. Ecotoxicology and environmental safety, 130, 185-192.(2016) .

[19] K.K.Ali, S.S.Shafik, H.A., S. S., Husain," Radiological Assessment of NORM Resulting From Oil and Gas Production Processing in South Rumaila Oil Field, Southern Iraq". Iraqi Journal of Science, 58(2C), 10371050. (2017).

[20] K.Ail,D.B.Ibraheem, " Radiological hazard Assessment Due to Natural Occurring Radioactive Materials (NORM) in Oil and Gas Production Industry-East Baghdad Oil Field". Iraqi J. Sci., 58, 115-126.(2017) . 